\title{
INTERNATIONALIZATION OF THE BUTTER MARKET
}

\author{
JOANNA BARAN
}

\begin{abstract}
The aim of the paper was to define geographic scope of internationalization the butter market based on Elzinga-Hogarty method.. Using secondary data (Food and Agriculture Organization, Institute of Agricultural and Food Economics) were find that the butter market is international in the scope, and this scope is evolving from country to semi-global and next to regional. Butter market consists only of 11th EU countries in 2014. Such market has production of 3361 thousand tones, consumption of 3292 thousand tones and export and import at the level of 317 thousand tones, 238 thousand tones, respectively.
\end{abstract}

Keywords: delineation of geographic scope, internationalization, butter market, Elzinga-Hogarty method.

JEL codes: D4, F15, K21, L66.

\section{Introduction}

Internationalisation is a complex phenomenon which can be analysed at various levels and in various dimensions: economic, scientific, political and legal, socio-cultural (Müller, 2003), and taking into account different perspectives (Daszkiewicz and Wach, 2012). As part of economic sciences, internationalisation can be considered at three main levels: on a macro scale (internationalisation of economies), meso scale (internationalisation of sectors/markets) and micro scale (internationalisation of enterprises) (Witek-Hajduk, 2010). The literature emphasises that internationalisation at all levels is a function of the motives and inclinations of enterprises for foreign expansion, including investing in development outside the home country, as well as for cooperation with foreign partners in other forms (Oczkowska, 2007). The majority of

Dr Joanna Baran, Szkoła Główna Gospodarstwa Wiejskiego w Warszawie, Wydział Nauk Ekonomicznych, Katedra Logistyki, ul. Nowoursynowska 166, 02-787 Warszawa (joanna_baran@sggw.pl). 
contemporary publications and scientific research carried out focused on the micro level, i.e. the internationalisation of enterprises, while there are only a few studies regarding the analysis of the internationalisation of sectors.

Despite the multitude of theories and models explaining internationalisation, there is no approach which would comprehensively explain this phenomenon. On the basis of the literature review, several takes on defining internationalisation emphasising a different element can be distinguished.

In the first group of definitions, internationalisation is perceived as a sequential process, occurring in stages, in which an enterprise moves from activity on the domestic market to operations on foreign markets (Daszkiewicz, 2017). The gradual increase in such extension of operations is often explained by the gradual acquisition of knowledge about foreign markets. This approach to internationalisation is presented, e.g. by Swedish scientists, creators of the Uppsala model-Johanson and Vahlne (1977), as well as Welch and Luostarinen (1988), Melin (1992), Przybylska (2005) and Fonfara (2009).

In the second group of definitions, the most important factor of internationalisation are business connections (networks) between enterprises on the international market. This approach can be seen, for instance, in the definitions of: Johanson and Mattsson (1993), Johanson and Vahlne (2009), Nowakowski (2005) and Pierścionek (2011).

The third approach to internationalisation connects the internationalisation process with the involvement of resources of the enterprise/sector (including capital and human resources) in the activity abroad - this approach is supported by the definitions of Andersen (1997), Ahokangas (1998), Duliniec (2004).

Another approach equates internationalisation with various forms of internationalisation of an enterprise. The literature presents active and passive forms of entry into foreign markets (Duliniec 2004). Active internationalisation is one associated with foreign expansion of the enterprise. In turn, passive internationalisation occurs when enterprises build connections with foreign companies without operating outside the home country. Forms of internationalisation include: export, import, sale of licences, franchising, leasing, foreign production/commercial branch, joint venture and strategic alliance with a foreign partner, etc.

Some researchers treat internationalisation as part of a strategic process where decisions should be made regarding the selection of target markets, forms of entering foreign markets, time and scale of the entry, as well as the scope of resources involved (Andersen and Buvik, 2002; Hill, 2013).

Many researchers also define the internationalisation process as an extension of the geographic scope of markets, products and forms of activity. An enterprise/sector covers new geographical areas with its activity, changing from the national scope through international to global (Rymarczyk, 2004; Dulieciec, 2004; Strzyżewska, 2005; Gorynia, 2007).

According to the sequential theories of internationalisation, the measurement of internationalisation at the market/sector level should take into account two dimensions: intensity and geographic scope (Hollensen, 2004). The intensity of 
internationalisation determines the degree of involvement of a given sector in the relations with foreign markets within various forms (inter alia, trade, contractual and investment) (Daszkiewicz and Wach, 2013). In turn, the second dimension concerns determining the geographic scope of expansion of a given sector as part of various actions.

The internationalisation process can be analysed using quantitative and qualitative methods. The quantitative methods of measuring internationalisation include, above all, indicators dedicated to measuring the intensity and/or spatial aspects of internationalisation. Mainly three indicators are used within this group: the Transnationality Index - TNI (UNCTAD, 1995), the TASI (Ietto-Gillies, 1998) and the degree of internationalisation - DOI (Sullivan, 1994). However, these are indicators dedicated to the assessment of internationalisation at the level of enterprises, not markets. In turn, methods which can be used to determine the spatial dimension of internationalisation at the sector level are those based on the movement of goods, e.g. the Elzinga-Hogarty method (1973, 1978), the Sleuwaegen (1994) concept and the concept of Makhija, Kim and Williamson (1997). The qualitative methods of measuring the foreign expansion of sectors include, among others, the concept of Porter (1998), Yip (2004), Lassere (2003), Stonehous, Hamill, Campbell and Purdie (2001) as well as Pietrzak (2014).

Studies of internationalisation within the framework of this are carried out at the market level. It should be noted that two concepts related to defining the market emerge from the literature on the subject - one concerns the supply side and the other the demand side (Gorynia, Jankowska and Maślak, 2000; Jankowska, 2005; Gorynia and Łaźniewska, 2010; Pietrzak 2014). There are also approaches which take into account both the demand and supply side of the market, as well as emphasising the importance of the third dimension - spatial (geographical area, territory, geographic scope) as a complement to the market definition (Wrzosek, 1998; Kotler, 2005; Stanton, 1981; Pietrzak, 2014). As part of this research, it was assumed that the market is defined taking into account the following three dimensions: 1. supply, i.e. sellers offering products with a high rate of substitution, 2. demand, i.e. buyers with specific needs, 3. geographical area.

The problem of defining the geographic scope of the butter market was raised in the works of Roman (2016, 2017), Pietrzak and Roman (2018). However, these studies concern only 2013 and 2015, and it is not possible to indicate the directions of changes in the geographical expansion of the market in butter on their basis, which in turn is important for identifying the course of the internationalisation process. Therefore, the objective of this article is to determine, using the ElzingaHogarty method, changes in the geographic scope of internationalisation of the butter market in Poland in 1990-2014. Taking 1990 as the beginning of the analysis was related to the beginning of major changes in the dairy sector resulting from the system change in Poland. The analysis ends on 2014 due to the fact that the most up-to-date data in the databases of the Food and Agriculture Organisation of the United Nations (FAO) regarding production of butter at the time of calculations was available for this year. 


\section{Research methodology}

The Elzinga-Hogarty method was used to determine the spatial dimension of internationalisation of the butter market. Using the movements of goods, the Elzinga-Hogarty method reflects shifts in demand and supply between areas. It is based on the verification of two tests - the LOFI (Little-Out-From-Inside) and the LIFO (Little-In-From-Outside) (Elzinga and Hogarty, 1973; Elzinga and Hogarty, 1978; Elzinga, 1981). The calculation method for these tests is shown in formulas 1 and 2. Positive verification of the LOFI test means that a given geographic area can be considered a single market, as companies located on this market have only a small part of their turnover outside its area. In turn, positive verification of the LIFO test means that the analysed market is a separate geographic market, and it occurs when only a small part of the product consumed on a given geographic market is imported from an external area.

$$
\begin{aligned}
& \text { LOFI }=\left[\frac{\text { production-export }}{\text { production }}\right] \times 100 \% \\
& \text { LIFO }=\left[\frac{\text { consumption-import }}{\text { consumption }}\right] \times 100 \%
\end{aligned}
$$

Therefore, the geographic market is defined as the smallest area where the percentage of deliveries of a given product - both from the outside and targeted at the outside - is small. The authors of the method define given market as strongly (clearly) separated when the LOFI and LIFO values are simultaneously at least $90 \%$. Therefore, it was assumed that the LOFI and LIFO tests must be met at the level of $90 \%$ ("strong" market). If at least one of the tests is below the assumed criterion, the area of a given market should be increased by "adding" markets (countries) until reaching the indicated percent thresholds for both tests, at the same time (Roman, 2016; Pietrzak, Roman and Mucha, 2016a,b). The butter market in Poland was the starting point for the analysis. This market concerned cows' milk products covered by the customs nomenclature code 040510 , not including dairy spreads. Data of the FAO and the Institute of Agricultural and Food Economics - National Research Institute (IERiGŻ-PIB) was the source of research materials.

\section{Research results}

Table 1 presents the results of the LOFI and LIFO tests for the market in butter with reference to 54 countries for selected years from the period of 1990-2014. The analysis carried out indicates that the maximal domestic scope of the butter market in the analysed years was demonstrated by countries from North America (the USA and partly Canada) and some countries from Asia (Korea, Turkey, Japan), in Europe such a scope was identified only in Switzerland. South America, Colombia and since 2005 also Brazil were characterised by maximal domestic scope 
of the butter market. The lack of detailed data at a lower level than domestic makes it impossible to verify whether maybe in one of the above-mentioned countries the butter market had, for example, local character.

In the case of the butter market in Poland, it was observed that in 1990, 1995 and 2000 it was a market of a domestic scope, and after 2005 the geographic scope of the market was wider than domestic (Table 1). This was influenced by Poland's accession to the EU and greater access to the foreign market and as a result in 2005 about $20 \%$ of the butter produced was sold outside the domestic market, while in 2000 only $2 \%$.

Based on the secondary data of IERiGŻ-PIB, the analysis of the scope of the butter market in Poland in 1991-2014 was carried out. Table 2 presents the results of partial LOFI and LIFO tests for Poland together with their interpretation. "YES" means that both tests simultaneously indicate the result at least at the level of $90 \%$, and "NO" that the result of at least one of the tests is below the required threshold allowing to recognise the area of Poland as a geographic market for a given product within the meaning of the Elzinga-Hogarty method. It was found that from 1994 to 2003 (excluding 2001), the butter market in Poland was a separate geographic market with a domestic scope. In 2004-2014, the LOFI test was not met which means that companies operating on the butter market in Poland made over $10 \%$ of their turnover outside this market. And since 2010 the LIFO test also has not been met which means that more than $10 \%$ of butter consumed in Poland was imported from outside.

In connection with the above, taking the butter market in Poland as a starting point, its geographic scope in 2005 and 2014 was determined based on the ElzingaHogarty method. The market in butter was increased by "adding" successively the country with which the largest trade was conducted until reaching $90 \%$ in both LOFI and LIFO tests. Tables 3 and 4 present a step-by-step order of adding countries forming in total the butter market in 2005 and 2014, defined according to the Elzinga-Hogarty method. 
Table 1

The LIFO and LOFI tests related to the butter market in selected countries of the world

\begin{tabular}{|c|c|c|c|c|c|c|c|c|c|c|c|c|}
\hline \multirow{2}{*}{ Country } & \multicolumn{2}{|c|}{1990} & \multicolumn{2}{|c|}{1995} & \multicolumn{2}{|c|}{2000} & \multicolumn{2}{|c|}{2005} & \multicolumn{2}{|c|}{2010} & \multicolumn{2}{|c|}{2014} \\
\hline & LOFI & LIFO & LOFI & LIFO & LOFI & LIFO & LOFI & LIFO & LOFI & LIFO & LOFI & LIFO \\
\hline \multicolumn{13}{|c|}{ EUROPE } \\
\hline Austria & 97 & 99 & 95 & 94 & 92 & 85 & 92 & 67 & 93 & 68 & 94 & 69 \\
\hline Belgium & -15 & -18 & -43 & -52 & 6 & 6 & -21 & -28 & -45 & -57 & -249 & -375 \\
\hline Belarus & b.d. & b.d. & 76 & 98 & 74 & 100 & 40 & 98 & 39 & 99 & 48 & 97 \\
\hline Bulgaria & 100 & 82 & 96 & 72 & 100 & 53 & -82 & -134 & -10 & -3 & -5 & -1 \\
\hline Croatia & b.d. & b.d. & 89 & 93 & 70 & 66 & 44 & 54 & 74 & 76 & 52 & 45 \\
\hline Czech Republic & 90 & 97 & 63 & 100 & 65 & 98 & 76 & 86 & 78 & 61 & 74 & 45 \\
\hline Denmark & 46 & 82 & 11 & 21 & 12 & 19 & -65 & -126 & -65 & -84 & 20 & 32 \\
\hline Estonia & b.d. & b.d. & 15 & 35 & 38 & 67 & 38 & 96 & 28 & 71 & 43 & 66 \\
\hline Finland & 41 & 100 & 64 & 98 & 43 & 99 & 35 & 98 & 43 & 93 & 53 & 93 \\
\hline France & 82 & 86 & 81 & 73 & 84 & 72 & 82 & 72 & 80 & 66 & 83 & 65 \\
\hline Greece & 97 & 38 & 97 & 33 & 99 & 41 & 98 & 23 & 84 & 8 & 87 & 20 \\
\hline Spain & 93 & 89 & -3 & -14 & 52 & 64 & 20 & 40 & -1 & -2 & 64 & 54 \\
\hline Netherlands & -10 & -23 & -38 & -176 & 5 & 7 & -53 & 10 & -36 & 11 & -6 & -12 \\
\hline Ireland & 54 & 98 & 3 & 67 & 18 & 85 & 18 & 89 & 1 & 8 & 13 & 78 \\
\hline Iceland & b.d. & b.d. & b.d. & b.d. & b.d. & b.d. & 65 & 100 & 74 & 100 & 100 & 100 \\
\hline Lithuania & b.d. & b.d. & 38 & 99 & 40 & 91 & 48 & 95 & 65 & 86 & 39 & 70 \\
\hline Latvia & b.d. & b.d. & 83 & 100 & 64 & 81 & 52 & 88 & 48 & 60 & 43 & 59 \\
\hline Grmany & 79 & 83 & 86 & 76 & 88 & 74 & 82 & 75 & 72 & 67 & 70 & 73 \\
\hline Norway & 42 & 99 & 73 & 100 & 76 & 98 & 88 & 97 & 86 & 99 & 100 & 97 \\
\hline Poland & 94 & 99 & 92 & 100 & 98 & 91 & 79 & 97 & 85 & 88 & 80 & 87 \\
\hline Portugal & 67 & 91 & 65 & 91 & 69 & 80 & 63 & 63 & 21 & 35 & 52 & 62 \\
\hline Russja & b.d. & b.d. & 99 & 63 & 98 & 83 & 99 & 75 & 99 & 72 & 98 & 64 \\
\hline Romania & 100 & 75 & 99 & 94 & 99 & 85 & 98 & 68 & 95 & 60 & 97 & 55 \\
\hline Slovakia & b.d. & b.d. & 97 & 90 & 84 & 96 & 84 & 68 & 65 & 30 & 32 & 15 \\
\hline Slovenia & b.d. & b.d. & 77 & 100 & 38 & 74 & 62 & 88 & 85 & 81 & 93 & 61 \\
\hline Switzerland & 100 & 90 & 100 & 94 & 100 & 83 & 100 & 95 & 91 & 99 & 92 & 100 \\
\hline Sweden & 55 & 100 & 60 & 100 & 67 & 100 & 66 & 97 & 53 & 62 & 95 & 76 \\
\hline Ukraine & b.d. & b.d. & 65 & 100 & 77 & 99 & 80 & 100 & 99 & 95 & 90 & 94 \\
\hline Hungary & 69 & 100 & 82 & 99 & 94 & 95 & 79 & 68 & 67 & 34 & 73 & 32 \\
\hline Great Britain & 72 & 47 & 61 & 43 & 66 & 41 & 65 & 40 & 78 & 47 & 65 & 47 \\
\hline Italy & 88 & 67 & 87 & 71 & 91 & 75 & 86 & 68 & 75 & 52 & 97 & 75 \\
\hline \multicolumn{13}{|c|}{ ASIA } \\
\hline China & 97 & 77 & 87 & 70 & 93 & 72 & 97 & 70 & 96 & 72 & 97 & 52 \\
\hline Iran & 100 & 74 & 100 & 84 & 100 & 87 & 100 & 81 & 99 & 74 & 100 & 78 \\
\hline Israel & 86 & 100 & 99 & 86 & 100 & 88 & 100 & 94 & 100 & 79 & 100 & 85 \\
\hline Japan & 100 & 92 & 100 & 98 & 100 & 100 & 100 & 94 & 100 & 95 & 100 & 84 \\
\hline Kazakhstan & b.d. & b.d. & 90 & 89 & 99 & 36 & 98 & 72 & 100 & 65 & 99 & 67 \\
\hline Korea & 100 & 100 & 100 & 99 & 100 & 98 & 100 & 92 & 100 & 90 & 100 & 93 \\
\hline Turcey & 100 & 97 & 100 & 97 & 100 & 96 & 100 & 95 & 100 & 92 & 100 & 89 \\
\hline \multicolumn{13}{|c|}{ AFRICA } \\
\hline Egypt & 100 & 46 & 100 & 40 & 100 & 43 & 100 & 56 & 99 & 41 & 100 & 41 \\
\hline Marocco & 100 & 38 & 100 & 36 & 100 & 38 & 100 & 36 & 100 & 52 & 100 & 53 \\
\hline Tunisia & 100 & 28 & 99 & 56 & 98 & 71 & 100 & 61 & 100 & 98 & 100 & 100 \\
\hline \multicolumn{13}{|c|}{ NORTH AMERICA } \\
\hline Canada & 96 & 100 & 94 & 99 & 92 & 84 & 77 & 74 & 92 & 92 & 99 & 91 \\
\hline USA & 91 & 100 & 95 & 100 & 100 & 97 & 99 & 94 & 93 & 98 & 93 & 98 \\
\hline
\end{tabular}


cont. Table 1

\begin{tabular}{|c|c|c|c|c|c|c|c|c|c|c|c|c|}
\hline \multicolumn{13}{|c|}{ CENTRAL AMERICA } \\
\hline Mexico & 100 & 58 & 99 & 60 & 100 & 31 & 95 & 26 & 100 & 34 & 71 & 33 \\
\hline Honduras & 100 & 97 & 99 & 81 & 76 & 78 & 87 & 77 & 84 & 89 & 80 & 97 \\
\hline \multicolumn{13}{|c|}{ SOUTH AMERICA } \\
\hline Argentina & 83 & 100 & 87 & 98 & 89 & 100 & 97 & 100 & 79 & 96 & 80 & 99 \\
\hline Bolivia & b.d. & 73 & b.d. & 98 & 96 & 89 & 41 & 46 & 12 & 74 & 41 & 90 \\
\hline Brazil & 100 & 86 & 100 & 80 & 100 & 87 & 98 & 100 & 95 & 98 & 96 & 99 \\
\hline Chile & 100 & 83 & 100 & 75 & 98 & 83 & 94 & 84 & 85 & 94 & 94 & 79 \\
\hline Columbia & 100 & 100 & 100 & 100 & 100 & 100 & 98 & 100 & 99 & 100 & 99 & 100 \\
\hline Uruguay & 5 & 100 & 59 & 99 & 67 & 100 & 29 & 100 & 39 & 100 & 33 & 94 \\
\hline Venezuela & 98 & 88 & 98 & 46 & 100 & 63 & 98 & 81 & 100 & 37 & 99 & 34 \\
\hline \multicolumn{13}{|c|}{ OCEANIA } \\
\hline Australia & 69 & 99 & 39 & 95 & 37 & 86 & 54 & 91 & 56 & 81 & 61 & 75 \\
\hline Noew Zeland & 16 & 100 & 12 & 100 & -4 & 105 & 16 & 96 & -6 & 103 & -14 & 101 \\
\hline
\end{tabular}

Note: the negative value of the LIFO and LOFI test means that the export/import volume was higher than the production/consumption of the dairy product.

Grey colour of a field means that in a given year the LIFO or LOFI test was met at the level of $\geq 90 \%$, while a black field means that in a given year both tests were met at the level of $\geq 90 \%$.

Consumption was calculated in a balance manner as production + import - export

Source: own calculations based on the FAO data.

The LIFO and LOFI tests for the market in butter in Poland in 1991-2014

\begin{tabular}{|c|c|c|c|c|c|c|c|}
\hline Year & $\begin{array}{c}\text { Production } \\
\text { (thousand tonnes) }\end{array}$ & $\begin{array}{c}\text { Export } \\
\text { (thousand tonnes) }\end{array}$ & $\begin{array}{c}\text { Import } \\
\text { (thousand tonnes) }\end{array}$ & $\begin{array}{c}\text { Consumption } \\
\text { (thousand tonnes) }\end{array}$ & $\begin{array}{c}\text { LOFI } \\
\text { test }\end{array}$ & $\begin{array}{c}\text { LIFO } \\
\text { test }\end{array}$ & $\begin{array}{r}\text { Tests } \\
\geq 90 \%\end{array}$ \\
\hline 1991 & 191.2 & 7.5 & 40.0 & 295.5 & 96 & 86 & $\mathrm{NO}$ \\
\hline 1992 & 153.8 & 1.3 & 38.0 & 220.4 & 99 & 83 & NO \\
\hline 1993 & 146.4 & 18.5 & 19.7 & 206.8 & 87 & 90 & NO \\
\hline 1994 & 119.8 & 8.0 & 3.0 & 198.1 & 93 & 98 & YES \\
\hline 1995 & 122.9 & 9.5 & 0.3 & 129.2 & 92 & 100 & YES \\
\hline 1996 & 131.7 & 13.1 & 0.4 & 143.2 & 90 & 100 & YES \\
\hline 1997 & 139.0 & 3.0 & 4.9 & 152.6 & 98 & 97 & YES \\
\hline 1998 & 146.0 & 5.0 & 1.0 & 157.3 & 97 & 99 & YES \\
\hline 1999 & 134.6 & 2.7 & 7.6 & 162.0 & 98 & 95 & YES \\
\hline 2000 & 139.1 & 3.0 & 12.3 & 143.4 & 98 & 91 & YES \\
\hline 2001 & 154.0 & 18.6 & 3.5 & 152.6 & 88 & 98 & $\mathrm{NO}$ \\
\hline 2002 & 153.9 & 11.8 & 4.6 & 157.0 & 92 & 97 & YES \\
\hline 2003 & 167.0 & 9.2 & 5.3 & 161.4 & 94 & 97 & YES \\
\hline 2004 & 177.2 & 27.6 & 4.1 & 152.0 & 84 & 97 & NO \\
\hline 2005 & 178.1 & 36.8 & 3.6 & 142.7 & 79 & 97 & NO \\
\hline 2006 & 173.3 & 24.1 & 4.7 & 142.6 & 86 & 97 & NO \\
\hline 2007 & 181.9 & 32.1 & 6.6 & 138.0 & 82 & 95 & NO \\
\hline 2008 & 182.5 & 30.5 & 6.7 & 133.4 & 83 & 95 & NO \\
\hline 2009 & 170.2 & 18.1 & 9.9 & 133.4 & 89 & 93 & NO \\
\hline 2010 & 177.4 & 26.9 & 14.3 & 124.2 & 85 & 88 & NO \\
\hline 2011 & 171.4 & 34.1 & 14.4 & 119.6 & 80 & 88 & NO \\
\hline 2012 & 171.6 & 31.2 & 12.2 & 115.0 & 82 & 89 & NO \\
\hline 2013 & 172.5 & 32.5 & 13.6 & 114.9 & 81 & 88 & NO \\
\hline 2014 & 179.6 & 35.7 & 14.9 & 114.9 & 80 & 87 & NO \\
\hline
\end{tabular}

Note: Consumption was calculated as the product of population size and annual consumption of butter per capita. Grey colour of a field means that in a given year the LIFO or LOFI test was met at the level of $\geq 90 \%$ Source: own calculations based on data Rynek Mleka (1990-2017). 
In 2005, the LOFI test for the butter market in Poland was not met at the level of $90 \%$ and was lower than the LIFO, which is why the largest recipient of butter, i.e. Germany, was added to Poland (Table 3). After adding Germany, both the LOFI and LIFO tests changed, but they were still not met at the level of $90 \%$. The market created by Poland+Germany conducted the largest trade exchange with the Netherlands, therefore it was added to the analysed market. As the Poland+Germany+the Netherlands market still did not meet the tests, further countries with the largest trade exchange with the analysed market were added until adding Taiwan and obtaining the assumed percent thresholds for the LOFI and LIFO tests.

From the mid-1990s until the accession to the EU, foreign trade in butter was small and characterised by volatility which was mainly determined by low world prices and the lack of subsidisation possibilities. Until this moment, the butter market in Poland, defined according to the Elzinga-Hogarty method, had a domestic scope. After the accession to the EU, the abolition of customs barriers resulted in an increase in butter exports, as a result of which in 2005 the (defined) butter market included Poland and 19 other countries from Europe, Asia, Africa, North America and Oceania (Table 3). The market in butter defined this way represented production at the level of 3361 thousand tonnes and consumption at the level of 3292 thousand tonnes, with import and export amounting to 238 thousand tonnes and 317 thousand tonnes, respectively. ${ }^{1}$ The market defined this way had a very large share (around 70\%) in global production and consumption, with a share in global export and import of $21 \%$ and $17 \%$, respectively.

The butter market defined with the Elzinga-Hogarty method in 2014 included Poland and the following 11 countries: the Czech Republic, Germany, the Netherlands, France, Ireland, Belgium, Great Britain, Italy, Denmark, Spain and Slovakia (Table 4). Countries added to Poland included significant world importers and exporters of butter. Compared to 2005, this market represented a similar volume of trade, production and consumption of butter, but its share in the global market in comparison to 2005 was smaller - $11 \%$ in terms of export and import and $36 \%$ in terms of production and consumption, respectively. In 2014, the share of the separated butter market in global export and import was $10 \%$ and $7 \%$, respectively, which indicates that in terms of movement of goods it was quite a homogeneous, fairly closed whole.

It can be noticed that the structure of the countries forming the butter market has changed. In 2005, the butter market in Poland had to be enlarged by 19 countries from 5 different continents for the LOFI and LIFO tests to be met (Fig. 1), while in 2014 by only 11 countries located in Europe (Fig. 2). Taking into account the analyses carried out, it can be assumed that according to the Elzinga-Hogarty method, until 2004 the butter market in Poland had a domestic scope, and then

\footnotetext{
${ }^{1}$ The volume of import and export refers only to import and export outside the defined market area, without the movements of goods between the countries forming the common market defined.
} 
in 2005-2014 it had a transnational character. ${ }^{2}$ It can be assumed that in 2005 the market in butter had a semi-global scope, while in 2014 regional scope - there was a concentration of directions of import and export of butter limited to Europe, mainly the EU countries.

Table 3

The geographic scope of the market in butter for Poland in 2005 based on the Elzinga-Hogarty method

\begin{tabular}{clccccccc}
\hline $\begin{array}{c}\text { Order } \\
\text { of } \\
\text { adding }\end{array}$ & Country & $\begin{array}{c}\text { Export } \\
\text { (thousand } \\
\text { tonnes) }\end{array}$ & $\begin{array}{c}\text { Import } \\
\text { thousand } \\
\text { tonnes) }\end{array}$ & $\begin{array}{c}\text { Production } \\
\text { (thousand } \\
\text { tonnes) }\end{array}$ & $\begin{array}{c}\text { Consumption } \\
\text { (housand } \\
\text { tonnes) }\end{array}$ & $\begin{array}{c}\text { LOFI } \\
\text { test }\end{array}$ & $\begin{array}{c}\text { LIFO } \\
\text { test }\end{array}$ & $\begin{array}{c}\text { Tests } \\
\geq 90 \%\end{array}$ \\
\hline 1 & Poland & 38 & 5 & 209 & 176 & 82.0 & 97.4 & NO \\
2 & + Germany & 111 & 120 & 659 & 668 & 83.2 & 82.0 & NO \\
3 & + Netherlands & 233 & 117 & 774 & 668 & 69.9 & 82.5 & NO \\
4 & + Ireland & 304 & 74 & 917 & 697 & 66.8 & 89.3 & NO \\
5 & + France & 327 & 159 & 1344 & 1186 & 75.7 & 86.6 & NO \\
6 & + Belgium & 364 & 168 & 1457 & 1270 & 75.0 & 86.8 & NO \\
7 & + Italy & 327 & 165 & 1586 & 1434 & 79.4 & 88.5 & NO \\
8 & + Great Britain & 314 & 235 & 1716 & 1647 & 81.7 & 85.8 & NO \\
9 & + Denmark & 282 & 181 & 1761 & 1670 & 84.0 & 89.1 & NO \\
10 & + New Zealand & 551 & 133 & 2140 & 1732 & 74.2 & 92.3 & NO \\
11 & + Egypt & 513 & 121 & 2173 & 1791 & 76.4 & 93.2 & NO \\
12 & + Iran & 477 & 127 & 2349 & 2010 & 79.7 & 93.7 & NO \\
13 & + Russia & 444 & 173 & 2602 & 2342 & 82.9 & 92.6 & NO \\
14 & + Mexico & 413 & 192 & 2621 & 2410 & 84.2 & 92.0 & NO \\
15 & + USA & 390 & 203 & 3232 & 3055 & 87.9 & 93.4 & NO \\
16 & + Saudi Arabia & 390 & 206 & 3236 & 3063 & 88.0 & 93.3 & NO \\
17 & + Morocco & 366 & 218 & 3256 & 3119 & 88.8 & 93.0 & NO \\
18 & + Azerbaijan & 345 & 207 & 3269 & 3141 & 89.4 & 93.4 & NO \\
19 & + Singapore & 330 & 216 & 3269 & 3164 & 89.9 & 93.2 & NO \\
20 & + Taiwan & 317 & 238 & 3361 & 3292 & 90.6 & 92.8 & YES \\
\hline
\end{tabular}

Note: the volume of import and export refers only to import and export outside the defined market area, without the movements of goods between the countries forming the common market.

Grey colour of a field means that in a given year the LIFO or LOFI test was met at the level of $\geq 90 \%$.

Source: own calculations based on the FAO data.

\footnotetext{
${ }^{2}$ Based on the approach of Luostarinen and Hellman (1993), the following geographic scopes have been distinguished: national sector (no internationalisation or pre-internationalisation, i.e. only passive forms of foreign expansion); regional sector (active forms of foreign expansion to several countries but within one continent); semi-global sector (active forms of foreign expansion to countries located on different continents); global sector (active forms of foreign expansion to countries located on all continents).
} 
Geographic scope of the market in butter for Poland in 2014

Table 4 based on the Elzinga-Hogarty method

\begin{tabular}{clccccccc}
\hline $\begin{array}{c}\text { Order } \\
\text { of } \\
\text { adding }\end{array}$ & \multicolumn{1}{c}{ Country } & $\begin{array}{c}\text { Export } \\
\text { (thousand } \\
\text { tonnes) }\end{array}$ & $\begin{array}{c}\text { Import } \\
\text { (thousand } \\
\text { tonnes) }\end{array}$ & $\begin{array}{c}\text { Production } \\
\text { (thousand } \\
\text { tonnes) }\end{array}$ & $\begin{array}{c}\text { Consumption } \\
\text { (thousand } \\
\text { tonnes) }\end{array}$ & $\begin{array}{c}\text { LOFI } \\
\text { test }\end{array}$ & $\begin{array}{c}\text { LIFO } \\
\text { test }\end{array}$ & $\begin{array}{c}\text { Tests } \\
\geq 90 \%\end{array}$ \\
\hline 1 & Poland & 34 & 11 & 181 & 158 & 80.9 & 92.8 & NO \\
2 & + Czech Republic & 34 & 25 & 203 & 194 & 83.4 & 87.3 & NO \\
3 & + Germany & 149 & 123 & 644 & 618 & 76.9 & 80.0 & NO \\
4 & + the Netherlands & 228 & 130 & 784 & 687 & 70.9 & 81.0 & NO \\
5 & + France & 213 & 222 & 1190 & 1199 & 82.1 & 81.5 & NO \\
6 & + Ireland & 280 & 150 & 1356 & 1226 & 79.3 & 87.8 & NO \\
7 & + Belgium & 247 & 106 & 1386 & 1246 & 82.2 & 91.5 & NO \\
8 & + G. Britain & 214 & 125 & 1529 & 1441 & 86.0 & 91.3 & NO \\
9 & + Italy & 185 & 126 & 1630 & 1571 & 88.6 & 92.0 & NO \\
10 & + Spain & 173 & 121 & 1665 & 1612 & 89.6 & 92.5 & NO \\
11 & + Denmark & 174 & 105 & 1707 & 1639 & 89.8 & 93.6 & NO \\
12 & + Slovakia & 164 & 103 & 1714 & 1653 & 90.5 & 93.8 & YES \\
\hline
\end{tabular}

Note: the volume of import and export refers only to import and export outside the defined market area, without the movements of goods between the countries forming the common market.

Grey colour of a field means that in a given year the LIFO or LOFI test was met at the level of $\geq 90 \%$ Source: own calculations based on the FAO data.

Foreign expansion of the butter market (transition from the domestic to supranational scope) was possible, e.g. thanks to the suitability of butter for transport and storage. Butter is included in the group of durable dairy products, as its durability in retail trade is 10-30 days, while storage durability in cold stores reaches even 12 months (Pijanowski and Zmarlicki, 1985; Pietrzak, 2002). It should be mentioned that butter is characterised by low specificity and is manufactured according to a similar technology in the majority of countries. Butter is a mass product and there is little possibility of diversifying it. Therefore, consumer preferences regarding this product may be similar which may push the processes of internationalisation and globalisation. On the other hand, as a result of the ongoing discussion on the harmfulness of animal fat, the demand for this product is decreasing. Thus, the observed changes in geographical directions and the intensity of expansion of this market should be attributed primarily to very high sensitivity of this market to cyclical changes. 


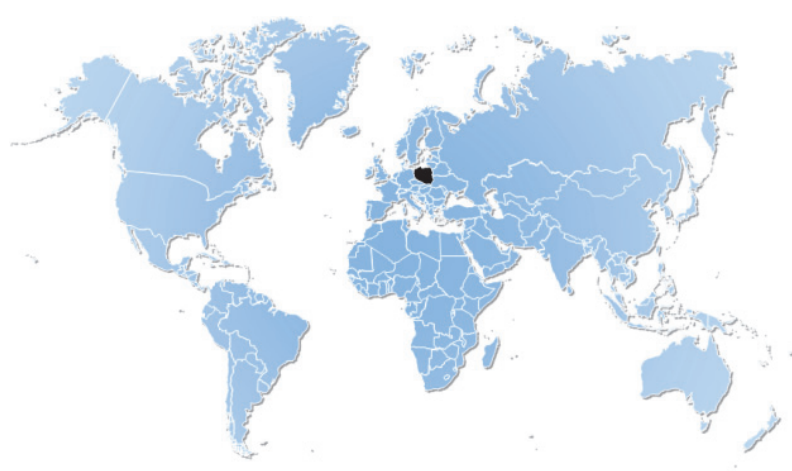

Fig. 1. Geographic scope of the market in butter in 1995 and 2000 according to the E-H method (national).

Source: own study.

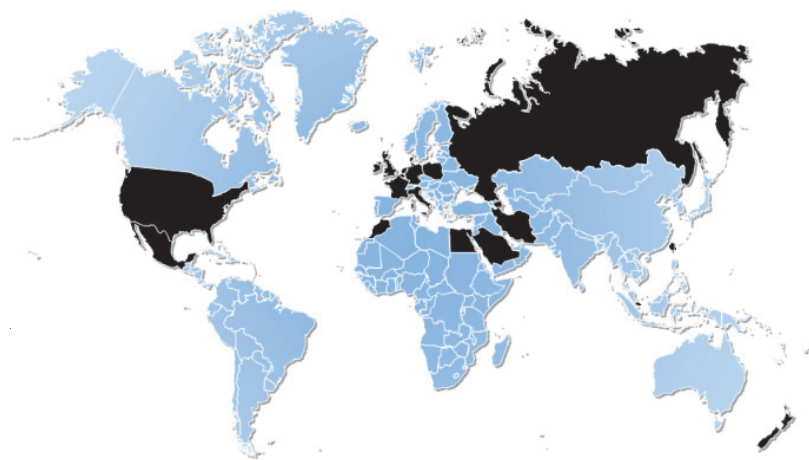

Fig. 2. Geographic scope of the market in butter in 2005 according to the E-H method (semi-global).

Source: own study.

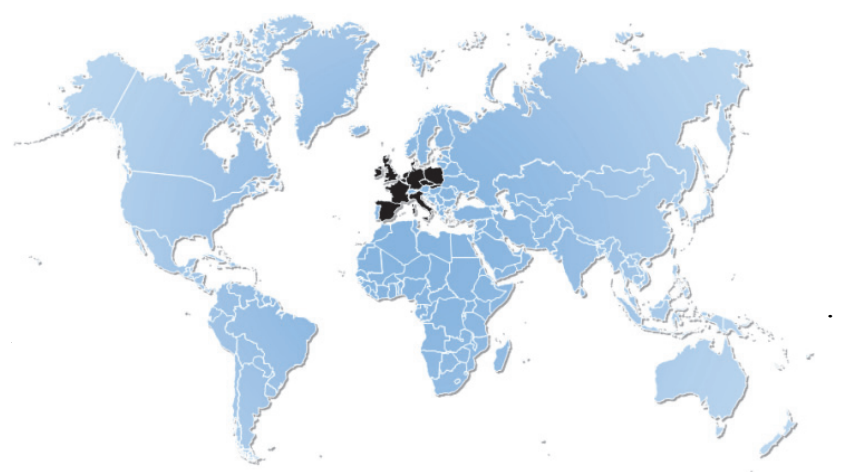

Fig. 3. Geographic scope of the market in butter in 2014 according to the E-H method (regional). Source: own study. 


\section{Summary and conclusions}

Internationalisation is a complex economic phenomenon and can be considered at three levels: macro-, meso- and microeconomic. Internationalisation can be analysed in two dimensions - within the intensity of involvement in activities abroad and within the geographic scope of these activities. The second dimension within the framework of the mesoeconomic approach is related to determination of the geographic boundaries of the market. Determination of geographical boundaries of foreign expansion of a given market also allows for the proper selection of methods to solve other research problems.

Application of the Elzinga-Hogarty method allowed identifying the directions of changes in the spatial scope of the butter market in Poland in 1990-2014. It can be assumed that until Poland's accession to the EU, the market in butter had a domestic scope, and then it increased its scope and became a semi-global market. In turn, in the second decade of the $21^{\text {st }}$ century, there was a concentration of directions of trade exchange and the scope decreased to regional. Therefore, it can be concluded that in the analysed period the processes of both internationalisation and de-internationalisation were observed on the butter market in Poland.

In addition, based on the analyses carried out, it can be assumed that the Polish butter market is connected to the international market - especially within the European Union countries. It gives, e.g. the basis to postulate that the policy and market and trade regulations for this market should be shaped taking into account the supranational level.

It is also worth noting that the results obtained may be influenced by the assumptions accepted in the Elzinga-Hogarty method. Firstly, according to the suggestion of the method's creators, the threshold for meeting the LIFO and LOFI tests was set at the level of $90 \%$, however, the adoption of lower thresholds would result in narrowing the geographical boundaries of the butter market. Secondly, the starting point for the analyses was the dairy sector in Poland. Beginning the analyses from a different starting point (another country) would probably also change the results obtained. In the context of the above limitations of the Elzinga-Hogarty method used, it is worth carrying out analyses of internationalisation of the butter market based on other approaches, e.g. indicative or qualitative, as part of further research. 


\section{References}

Ahokangas, P. (1998). Internationalization and resources: an analysis of processes in Nordic SMSs. Vaasa: Universitas Wasaensis.

Andersen, O. (1997). Internationalization and market entry mode: a review of theories and conceptual frameworks. Management International Review, 37, pp. 27-42.

Andersen, O., Buvik, A. (2002). Firms' internationalization and alternative approaches to the international customer/market selection. International Business Review, 11, pp. 347-363

Czapla, E. (2010). Powiązania długookresowe między stopami procentowymi Polski, Stanów Zjednoczonych i strefy euro. Zeszyty Naukowe Instytutu Ekonomii i Zarzadzania, 4, pp. 265-275.

Daszkiewicz, N. (2017). Internacjonalizacja przedsiębiorstw poprzez sieci. Wyniki badań ankietowych. Studia Ekonomiczne. Zeszyty Naukowe Uniwersytetu Ekonomicznego w Katowicach, No. 319, pp. 19-30.

Daszkiewicz, N., Wach, K. (2012). Internationalization of SMEs. Context, Models, Implementation. Gdańsk: Gdańsk University of Technology Publishers.

Daszkiewicz, N., Wach, K. (2013). Małe i średnie przedsiębiorstwa na rynkach międzynarodowych. Kraków: Wydawnictwo UE w Krakowie.

Duliniec, E. (2004). Marketing międzynarodowy. Warszawa: Polskie Wydawnictwo Ekonomiczne.

Elzinga, K.G. (1981). Defining Geografic Market Boundaries. Antitrust Bulletin, vol. 23, pp. 1-18.

Elzinga, K.G., Hogarty, T.F. (1973). The Problem of Geographic Market Delineation in Antimerger Suits. Antitrust Bulletin, vol. 18, pp. 45-81.

Elzinga, K.G., Hogarty, T.F. (1978). The Problem of Geographic Market Delineation Revisited: The Case of Coal. Antitrust Bulletin, vol. 23, pp. 1-18.

Fonfara, K. (2009). Istota i zakres procesu internacjonalizacji. In: K. Fonfara (ed.), Zachowania przedsiębiorstw $w$ procesie internacjonalizacji firmy (pp. 11-26). Podejście sieciowe. Warszawa: PWE.

Gorynia, M. (2007). Strategie zagranicznej ekspansji przedsiębiorstw. Warszawa: PWE.

Gorynia, M., Jankowska, B., Maślak, E. (2000). Branża jako przedmiot badań w ekonomii. Gospodarka Narodowa, No. 3, pp. 36-54.

Gorynia, M., Łaźniewska, E. (2010). Kompendium wiedzy o konkurencyjności. Warszawa: Wydawnictwo Naukowe PWN.

Hamulczuk, M. (2007). Powiązania cen wieprzowiny pomiędzy rynkiem polskim, duńskim i niemieckim. Problemy Rolnictwa Światowego, vol. XVII, pp. 195-206.

Hamulczuk, M., Klimkowski, C. (2011). Powiązania miedzy cenami ropy a cenami pszenicy w Polsce. Roczniki Nauk Rolniczych - Seria G, vol. 98, z. 3, pp. 176-190.

Hamulczyk, M., Gędek, S., Klimkowski, C., Stańko, S. (2012). Prognozowanie cen surowców rolnych na podstawie zależności przyczynowych. Warszawa: IERiGŻ-PIB.

Hill, Ch.W.L. (2013). International Business. Competing in the global marketplace. New York: McGraw-Hill/Irwin.

Hollensen, S. (2004). Global Marketing. A decision - oriented approach. London: Pearson.

Ietto-Gillies, G. (1998). Different Conceptual Frameworks for the Assessment of the Degree of Iinternationalization: an Empirical Analysis of Various Indices for the Top 100 Transnational Corporations. Transnational Corporations, vol. 7(1), pp. 1-19.

Jankowska, B. (2005). Międzynarodowa konkurencyjność branży na przykładzie polskiej branży budowlanej w latach 1994-2001. Poznań: Wydawnictwo Akademii Ekonomicznej w Poznaniu. 
Johanson, J., Mattsson, L.G. (1993). Internationalization of Industrial Systems - A Network Approach. In: P.J. Buckley, P. Ghauri (ed.), The Internationalization of the Firm. London: Academic Press.

Johanson, J., Vahlne, J.E. (1977). The internationalization process of the firm: a model of knowledge development and increasing foreign commitments. Journal of International Business Studies, vol. 8(1), pp. 23-32.

Johanson, J., Vahlne, J.E. (2009). The Uppsala Internationalization Process Model Revisited: From Liability of Foreignneess to Liability of Outsidership. Journal of International Business Studies, vol. 40(9), pp. 1411-1431.

Kotler, P. (2005). Marketing. Poznań: DW „Rebis”.

Kusideł, E. (2000). Modelowanie wektorowo-autoregresyjne VAR. Metodologia i zastosowanie w badaniach ekonomicznych. Łódź: Absolwent.

Lasserre, P. (2003). Global Strategic Management. New York: Palgrave Macmillan, Houndmills, Basingstoke.

Luostarinen, R., Hellman, H. (1993). Internationalization process and strategies of Finnish family enterprises. In: M. Virtanen (ed.), Proceedings of the Conference on the Development, Studies and Reports, Ministry of Trade and Industry, 59.

Makhija, M.V., Kim, K., Williamson, S.D. (1997). Measuring globalization of industries using a national industry. Journal of International Business Studies, Fourth Quarter, ProQuest, vol. 28(4), pp. 679-710.

Melin, L. (1992). Internationalization as a strategy process. Strategic Management Journal, 13, pp. 99-118.

Mickiewicz, T. (2012). Wybór w gospodarce. Wprowadzenie do ekonomii. Wydawnictwo WSE w Krakowie, WSIiZ w Rzeszowie, WSZiZ w Zamościu, Kraków-Rzeszów-Zamość.

Müller, A. (2003). Globalizacja - mit czy rzeczywistość. Globalizacja od A do Z. Bank i Kredyt, No. 5, pp. 35-58.

Nowakowski, M.K. (ed.) (2005). Biznes międzynarodowy. Od internacjonalizacji do globalizacji. Warszawa: SGH.

Oczkowska, R. (2007). Przedsiębiorstwo na rynku międzynarodowym. Uwarunkowania strategii internacjonalizacji i globalizacji. Kraków: Oficyna Wydawnicza AFM.

Pierścionek, Z. (2011). Zarządzanie strategiczne w przedsiębiorstwie. Warszawa: WN PWN.

Pietrzak, M. (2002). Strategie konkurencji przodujących przedsiębiorstw w sektorze przetwórstwa mleka. Warszawa: Wydawnictwo SGGW.

Pietrzak, M. (2014). Problem geograficznego zakresu rynków/sektorów w dobie globalizacji i regionalizacji. Zagadnienia Ekonomiki Rolnej, No. 1(338), pp. 3-21.

Pietrzak, M., Roman, M. (2018). The problem of geographical delimitation of agri-food markets: evidence from the butter market in European Union. Acta Scientiarum Polonorum. Oeconomia, No. 17(3), pp. 85-95. DOI: 10.22630/ASPE.2018.17.3.40.

Pietrzak, M., Roman, M., Mucha, M. (2016a). Określenie zasięgu geograficznego rynku cukru z wykorzystaniem metody Elzinga-Hogarty. Zagadnienia Ekonomiki Rolnej, No. 1(346), pp. 22-41.

Pietrzak, M., Roman, M., Mucha, M. (2016b). Zmiany we wspólnej organizacji rynku cukru a jego zasięg geograficzny. Zeszyty Naukowe SGGW - Problemy Rolnictwa Światowego, vol. 16, issue 2, pp. 9-18.

Pijanowski, E., Zmarlicki, S. (1985). Zarys chemii i technologii mleczarstwa. Vol. II. Warszawa: PWRiL. 
Porter, M.E. (1998). Strategia konkurencji. Metody analizy sektorów i konkurentów. Warszawa: PWE.

Przybylska, K. (2005). Proces internacjonalizacji przedsiębiorstwa w teorii ekonomicznej. Zeszyty Naukowe WSE w Bochni, No. 3, pp. 73-92.

Roman, M. (2016). Zastosowanie metody E-H do określenia zasięgu geograficznego rynku masła. Roczniki Naukowe SERIA, vol. XVIII, No. 3, pp. 298-302.

Roman, M. (2017). Uwarunkowania i kierunki zmian zasięgu geograficznego rynku mleka surowego w Polsce. Warszawa: Wydawnictwo SGGW.

Rymarczyk, J. (2004). Internacjonalizacja i globalizacja przedsiębiorstwa. Warszawa: PWE.

Rynek mleka. Stan i perspektywy (1900-2017). Analizy Rynkowe. Warszawa: IERiGŻ-PIB, ARR, MRiRW.

Seremak-Bulge, J., Roman, M. (2016). Sytuacja na światowym rynku mleka i jej wpływ na polski rynek i jego możliwości rozwojowe. In: S. Stańko (ed.), Sytuacja na światowych rynkach mięsa i produktów mleczarskich oraz jej wpływ na rynek krajowy i możliwości jego rozwoju (s. 105-154). Program Wieloletni 2015-2019, No. 31. Warszawa: IERiGŻ-PIB.

Sleuwaegen, L. (1994). The relevant antitrust market. European Economy, No. 57, pp. 109-129.

Stanton, W.J. (1981). Fundamentals of Marketing. New York: McGraw-Hill Inc.

Stonehouse, F., Hamill, J., Campbell, D., Purdi,e T. (2001). Globalizacja. Strategia i zarzadzanie. Warszawa: Wydawnictwo Felberg SJA.

Strzyżewska, M. (2005). Marketing na rynkach zagranicznych. In: M.K. Nowakowski (ed.), Biznes międzynarodowy. Od internacjonalizacji do globalizacji. Warszawa: Oficyna Wydawnicza SGH.

Sullivan, D. (1994). Measuring the Degree of Internationalization of a Firm. Journal of International Business Studies, vol. 25(2), pp. 325-342.

Szajner, P. (2017). Transmisja cen na rynku mleka w Polsce w latach 2004-2017. Zagadnienia Ekonomiki Rolnej, No. 4(353), pp. 3-23.

UNCTAD (1995). World Investment Report 1995. Transnational Corporations and Competitiveness. United Nations Conference on Trade and Development, New York - Geneva.

Welch, L.S., Luostarinen, R. (1988). Internationalization: evolution of a concept. Journal of General Management, vol. 14(2), pp. 34-55.

Werden, G.J., Froeb, L.M. (1993). Correlation, Causality, and All that Jazz: The Inherent Shortcomings of Price Tests for Antitrust Market Delineation. Review of Industrial Organization, 8, pp. 329-353.

Witek-Hajduk, M.K. (2010). Strategie internacjonalizacji polskich przedsiębiorstw w warunkach akcesji Polski do Unii Europejskiej. Warszawa: Oficyna Wydawnicza SGH.

Wrzosek, W. (1998). Funkcjonowanie rynku. Warszawa: PWE.

Yip, G.S. (2004). Strategia globalna. Warszawa: PWE. 


\title{
INTERNACJONALIZACJA RYNKU MASŁA
}

\begin{abstract}
Abstrakt
Głównym celem artykułu było określenie zmian zasięgu geograficznego procesów internacjonalizacji rynku masła w Polsce z wykorzystaniem metody bazującej na przepływach towarów (metoda Elzinga-Hogarty). Bazując na danych wtórnych FAO i IERiGŻ-PIB, stwierdzono, ze rynek masła w Polsce do 2004 roku miat zasieg krajowy, nastepnie po integracji z UE zasięg rozszerzyt sie do semi-globalnego, po czym nastapiła koncentracja ekspansji w ramach form handlowych do krajów UE i zasięg geograficzny zawęził się do regionalnego. W 2014 roku rynek masła obejmowat Polskę oraz 11 krajów będacych członkami Unii Europejskiej. Tak zdefiniowany rynek masła charakteryzowat sie produkcja na poziomie 3361 tys. ton, konsumpcja na poziomie 3292 tys. ton oraz eksportem i importem odpowiednio na poziomie 317 i 238 tys. ton.
\end{abstract}

Słowa kluczowe: zasięg geograficzny, internacjonalizacja, rynek masła, metoda Elzinga-Hogarty.

Accepted for print: 10.06.2019. 